\title{
Phaseolus Genetic Resources Grown in Campeche, Mexico
}

\author{
Fermín Orona-Castro1, Rogelio Lépiz-Ildelfonso², Juan Medina-Mendez¹, \\ Mónica Guadalupe Lozano-Contreras ${ }^{3}$, Mirna Hernández Pérez ${ }^{1}$ \\ ${ }^{1}$ Instituto Nacional de Investigaciones Forestales, Agrícolas y Pecuarias (INIFAP), Campo Experimental Edzná, \\ Km 15.5 Carretera Campeche-Tixmucuy, Campeche, México \\ ${ }^{2}$ Universidad de Guadalajara, Guadalajara, México \\ ${ }^{3}$ Instituto Nacional de Investigaciones Forestales, Agrícolas y Pecuarias (INIFAP), Campo Experimental Mocochá, \\ Km 25 Carretera Mérida-Motul, Yucatán, México \\ Email: orona.fermin@inifap.gob.mx
}

Received 18 November 2015; accepted 21 December 2015; published 24 December 2015

Copyright (C) 2015 by authors and Scientific Research Publishing Inc.

This work is licensed under the Creative Commons Attribution International License (CC BY).

http://creativecommons.org/licenses/by/4.0/

(c) (i)

\section{Abstract}

The protein intake of the population in the Yucatan Peninsula is based upon the different forms of beans naturally developed. The different ecotypes of creole beans that are grown traditionally have been displaced by improved varieties, thereby turning into a risk of losing a valuable source of germ-plasma. The present study is aimed to identify, collect and preserve several bean species genetic resources grown in Campeche, Mexico, in addition to the development of an identification card with the main phenotypic characteristics and yield components. A total of 33 different samples were collected from nine different municipalities statewide; out of those, 15 were Phaseolus vulgaris and 18 Phaseolus lunatus. The collected samples diversity is reflected in the range of growth habits from the bush to the indeterminate climbing species, being these the most representative with about 29 samples, many of those because of the way the planting is carried out, which is traditionally performed in association with the cultivation of corn. Early samples were identified in this diversity with their cycle ranging from 60 to 120 days after emergence. Samples of Phaseolus lunatus with 1.35 to 2.86 t/ha yield potential were also obtained.

\section{Keywords}

Creole Beans, Collect, Preserv, Genetic Variability

\section{Introduction}

The bean has had a rather long traditional consumption dating all the way back to pre-Hispanic times, presenting

How to cite this paper: Orona-Castro, F., Lépiz-Ildelfonso, R., Medina-Mendez, J., Lozano-Contreras, M.G. and Pérez, M.H. (2015) Phaseolus Genetic Resources Grown in Campeche, Mexico. Agricultural Sciences, 6, 1464-1471. 
a wide diversity for both wild and cultivated varieties [1]. Along the Yucatan peninsula, protein diet is based on beans naturally grown since the pre-Columbian era, differing in size (medium, small and large), shape (flat, round and kidney-shaped), plus color (white, black, brown, yellow, cream, purple, etc.). They represent valuable genetic resources with a high potential for the security of the regional food intake, providing a relevant contribution to reduce poverty due to their nutritional resource availability in underserved rural areas [2] [3].

Different bean varieties are cultivated along the state of Campeche; however, it is threatened the conservation of seeds. Due to changes in land use by livestock, use of agrochemicals, genetic erosion, population explosion, disaster, fire and release of improved varieties have resulted in the reduction of the genetic base and the gradual disappearance of native crops or wild [4].

When we lose the genetic diversity of a species and only a few copies of collection, the work of thousands of years of evolution is lost [5], as in the case of populations of wild beans (Phaseolus vulgaris L.) which are used by incipiently humans, nowadays. Many of those are tolerant to stress-inducing environments; moreover, their nutritional characteristics and quality may be exceptional, representing an untapped resource, thus [6].

The project "Food legumes inventory and conservation grown in the state of Campeche" was carried out with looking forward to maintaining the different bean varieties grown along the state of Campeche, throughout a plan aimed to encourage both the collecting and preservation of different edible bean variants, in several diverse species that are quite relevant for human nutrition. Consequently, the study was aimed to 1) characterize the germ-plasm richness, abundance and distribution of the Phaseolus wild and cultivated bean species; 2) develop passport identification with phenotypic characteristics and yield components; 3) preserve the genetic resources of several bean species grown in Campeche, Mexico.

\section{Materials and Methods}

\subsection{Collections}

Samples were collected between 2011 (10 samples were lunatus and 8 vulgaris) and 2012 (8 samples lunatus and 7 vulgaris). The town and municipality of collection were determined based upon several interviews with producers, looking forward to identify and trace the collection route were wild beans were traditionally grown in the state of Campeche, performing collections in the nine municipalities of Hecelchacán, Hopelchén, Tenabo, Campeche, Champotón, Calakmul, Escárcega, Candelaria and Carmen, plus along 39 towns (Figure 1).

\subsection{Establishment and Crop Handling}

All of the collected samples were established on the field in the town of San Antonio Cayal, located in the Campeche municipality $\left(19^{\circ} 45^{\prime} 08.14^{\prime \prime} \mathrm{N}\right.$ and $90^{\circ} 09^{\prime} 51.84^{\prime \prime} \mathrm{W}$, ASNM $\left.31 \mathrm{~m}\right)$; these were sown in plots of six rows and six meters long; the planting distance between rows was $80 \mathrm{~cm}$, plus $10 \mathrm{~cm}$ in between plants; a $50 \mathrm{~kg}$ density of seed per hectare was used. The cultivation conditions were under temporary planting, having August 24th, 2012 set as the cultivation date. The harvesting took place at the beginning of November for the early samples, coming to an end in the same year by December 29th with the late genotypes. The type of soil in this region is Luvisols known as K'ankab (classification according to the Mayan), red soils with high clay content but with permeable drainage [7].

The agricultural practice consisted on preparing the cultivation soil throughout two dragging phases, performing the second by cross; the trenching was then carried out, followed by the drawing of the plot size; the planting was done, afterwards. A basal fertilizer application was performed using ammonium phosphate in dosages of $80 \mathrm{~kg}$ per hectare, plus $30 \mathrm{~kg}$ of nitrogen per hectare. Both manual and chemical weed control, as well as pest control was performed; furthermore, tutors were also set on site because most of the Phaseolus collected were samples sown associated with corn and classified as type IV growth.

The data was recorded in order to differentiate the samples as flowering days, maturity days, grain color, flower color, grains number per pod, grain yield and growth habit; the bean evaluation manual was used for data evaluation [8].

\section{Results and Discussion}

A total of 33 Phaseolus samples were collected; 15 samples were from the vulgaris species and 18 were lunatus 


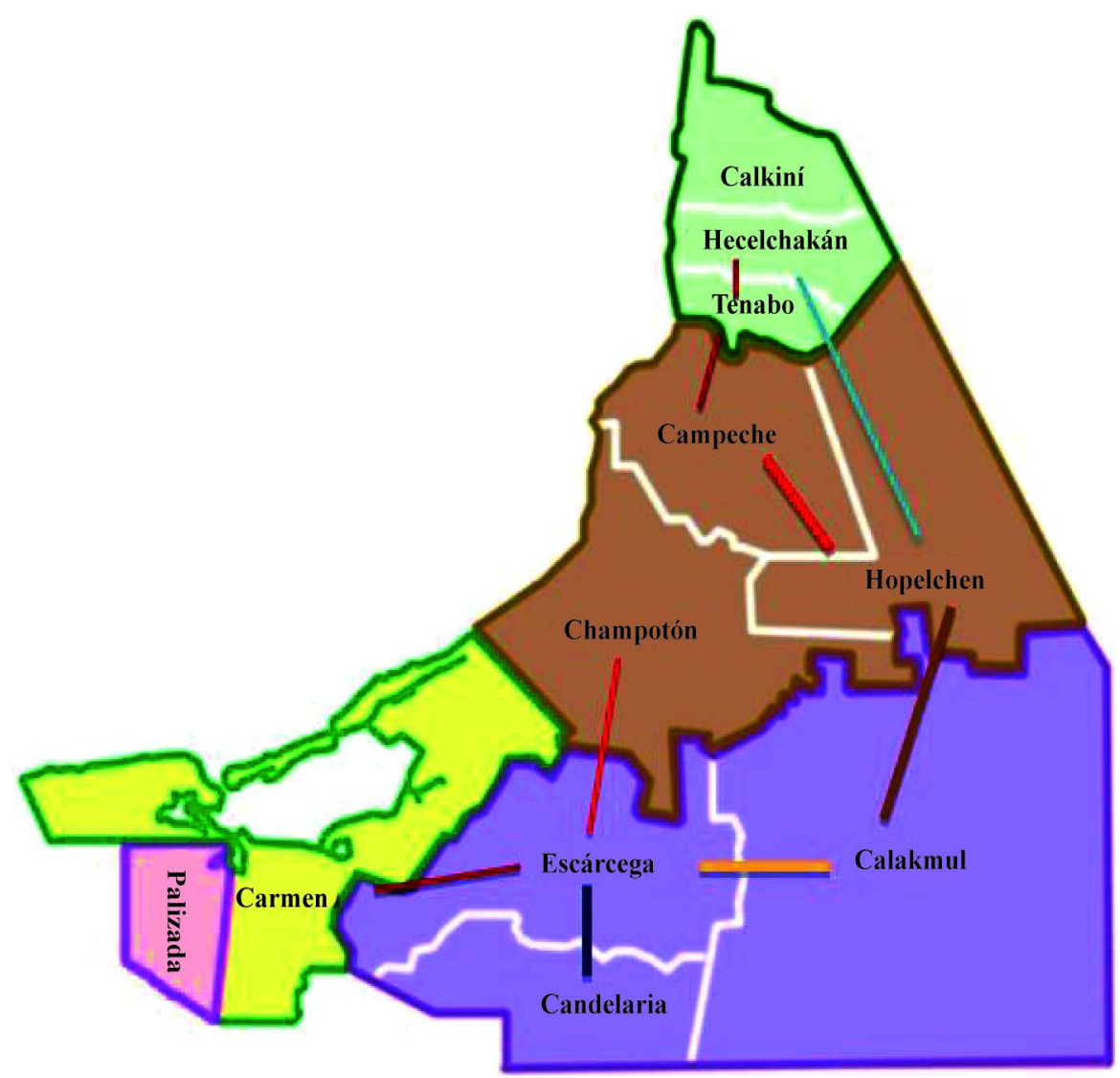

Figure 1. Routes traveled for the collection of wild Phaseolus species in the state of Campeche.

(Table 1). Four variants of the genotype locally known as the T'zamáa were identified in the sampling collection from the Hecelchacan, Hopelchen and Champotón municipalities (red sheath, purple short sheath and the last being long marbled sheath); the first two plus the last belong to the type IV or beans that require a tutor guide for their proper development (Figure 2); two Mejen buul variants were also found at the towns of Chencoh and Iturbide, in the Hopelchen municipality, one of short sheath and another of long. An early lunatus (60 days maturity) was found at the town of Dzitnup, in the Hecelchacán municipality; moreover, late lunatus samples (132 days maturity) were also found at the town of San Antonio Cayal, in the Campeche municipality.

\subsection{Genotype Geographical Distribution}

The largest number of Phaseolus genotypes were located in the Campeche municipality (21 genotypes), followed by the Champotón and Hecelchacán with 4 genotypes, respectively. The lowest number of genotypes was located in the municipalities of Hopelchén (2), Tenabo (1) and Escárcega (1) (Figure 3). It is noteworthy that in the municipalities that were not reported in Figure 3 (Tenabo, Calakmul, Candelaria and Carmen), the Phaseolus collection was performed; nevertheless, similarities among the Phaseolus species collected per town were determined during the evaluation of the field. The evaluation of the collected genetic variability was performed based upon the expression of the different morphological characteristics in each accession related to the plant, flower, sheath and grain vegetative growth. These characteristics were repeated in several accessions.

The lunatus species is recognized by the Mayan farmers as ib, ibes or lime bean; the cultivation of this bean in the region has played a key role in the diet of the Mayan culture, being the fourth most important crop for the traditional Mayan agriculture in the Yucatan peninsula [9]-[12]. Consequently, it is understood that many of the collected samples during harvesting belong to the lunatus species (Figure 4), being the Campeche municipality where the largest sample of this species were found (12 collections), compared to the vulgaris species (9 collections). 
Table 1. Origin, common name and characteristics of 33 bean populations collected in the state of Campeche during 2011 and 2012.

\begin{tabular}{|c|c|c|c|c|c|c|c|}
\hline Col. & Located & Common name & Beans color & $\begin{array}{c}\text { Days to } \\
\text { flowering }\end{array}$ & $\begin{array}{c}\text { Days to } \\
\text { maturity }\end{array}$ & $\begin{array}{c}\text { Weight of } \\
500 \text { seeds (g) }\end{array}$ & $\begin{array}{c}\text { Production } \\
\text { cycle }\end{array}$ \\
\hline C1 & Campeche & T’zamáa red sheath & Black & 40 & 113 & 98.94 & *Intermediate \\
\hline C2 & Hopelchén & Cole buul & Black & 38 & 115 & 103.38 & Intermediate \\
\hline C3 & Hecelchacán & Mejen ib & Red & 30 & 70 & 127.44 & Short \\
\hline C4 & Hecelchacán & Ibes white & White & 50 & 132 & 132.22 & Intermediate \\
\hline C5 & Hopelchén & Ibes munition & White & 42 & 112 & 142.62 & Intermediate \\
\hline C6 & Hecelchacán & Zot chet buul & Black & 35 & 80 & 112.5 & Long \\
\hline C7 & Campeche & Bush black beans & Black & 42 & 118 & 75.03 & Intermediate \\
\hline C8 & Campeche & Colored green beans & Red & 49 & 132 & 89.04 & Intermediate \\
\hline C9 & Champotón & Red creole beans & Red & 47 & 129 & 110.47 & Long \\
\hline $\mathrm{C10}$ & Champotón & Mejen buul & Black & 32 & 73 & 145.16 & Short \\
\hline C11 & Champotón & Rod bean red sheath & Red & 43 & 120 & 129.95 & Intermediate \\
\hline C12 & Campeche & T’zamáa green sheath & Black & 41 & 113 & 141.32 & Intermediate \\
\hline C13 & Campeche & T’zamáa Bush long sheath & Black & 35 & 85 & 131.5 & Intermediate \\
\hline C14 & Campeche & T’zamáa marbled sheath & Black & 42 & 115 & 120.89 & Intermediate \\
\hline C15 & Campeche & Ibes pinto creole & Pinto & 45 & 110 & 193.31 & Long \\
\hline C16 & Hecelchacán & Ibes white plane & White & 45 & 115 & 139.31 & Long \\
\hline C17 & Campeche & Charro beans & Red & 35 & 102 & 282.17 & Intermediate \\
\hline C18 & Campeche & Ibes cream plane & Cream & 43 & 113 & 136.97 & Intermediate \\
\hline C19 & Campeche & Ibes dark purple & Dark purple & 41 & 119 & 175.99 & Intermediate \\
\hline C20 & Campeche & Ibes light red & Red & 35 & 95 & 136.76 & Intermediate \\
\hline C21 & Campeche & Ibes light purple & Light purple & 35 & 95 & 167.21 & Long \\
\hline $\mathrm{C} 22$ & Escárcega & Ibes black plane & Black & 42 & 112 & 177.67 & Long \\
\hline $\mathrm{C} 23$ & Campeche & Creole Bush beans & Black & 30 & 73 & 87.07 & Intermediate \\
\hline C24 & Tenabo & Ibes pink & Pink & 30 & 90 & 132.62 & Long \\
\hline C25 & Campeche & Ibes light pink & Pink & 45 & 115 & 140.21 & Long \\
\hline C26 & Campeche & Ibes cream-black pinto & Cream-Black Pinto & 45 & 115 & 149.87 & Intermediate \\
\hline C27 & Campeche & Ibes white-black pinto & White-Black Pinto & 42 & 112 & 170.0 & Intermediate \\
\hline C28 & Campeche & Ibes black & Black & 42 & 112 & 159.86 & Long \\
\hline C29 & Campeche & Ibes fucsia & Fuscia & 30 & 90 & 133.86 & Intermediate \\
\hline C30 & Campeche & Ibes cream-black marbled & Cream-Black marbled & 43 & 113 & 165.28 & Intermediate \\
\hline C31 & Kesté & Bean pigeon paw & Red & 48 & 131 & 45.18 & Long \\
\hline C32 & Campeche & Ibes cream-pink pinto & Cream-Pink Pinto & 45 & 118 & 141.45 & Long \\
\hline C33 & Campeche & Red beans & Red & 45 & 118 & 85.38 & Intermediate \\
\hline
\end{tabular}

*Production cycle times: Short (60 - 90 days), Intermediate (91 - 120 days), Long (121 - 150 days) 

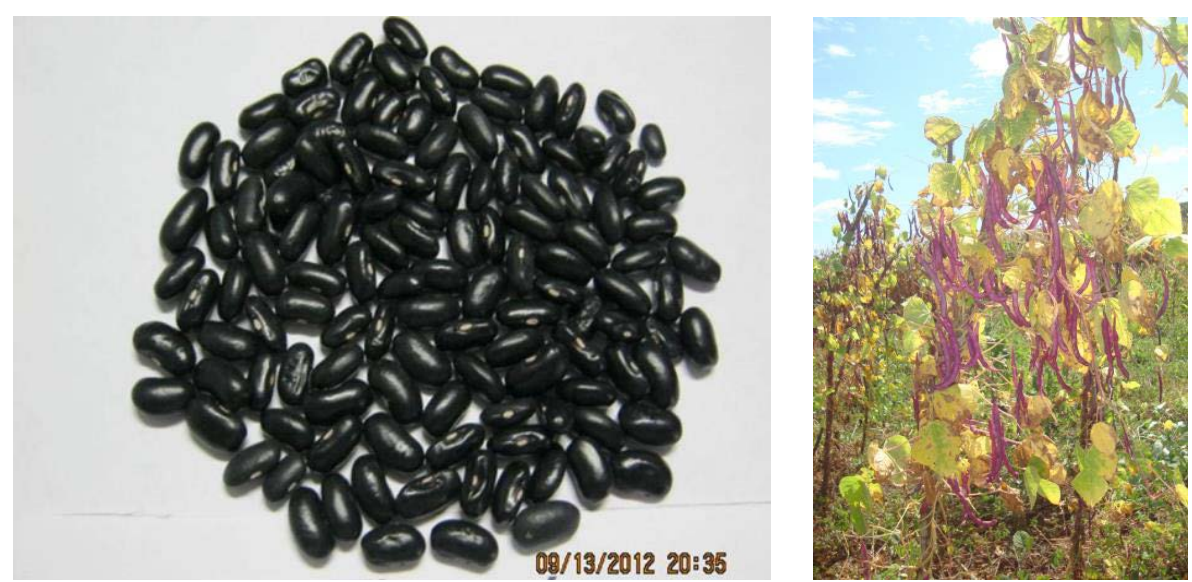

Figure 2. Grain and bean plants native Phaseolus vulgaris variety T'zamáa (red sheath) collected in the municipality Campeche.

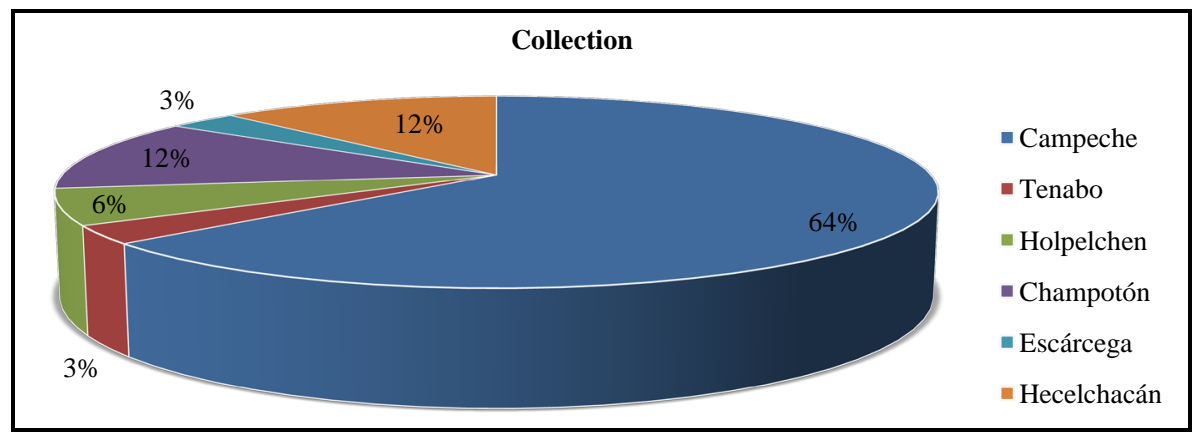

Figure 3. List of collections per municipality in the state of Campeche, Mexico.

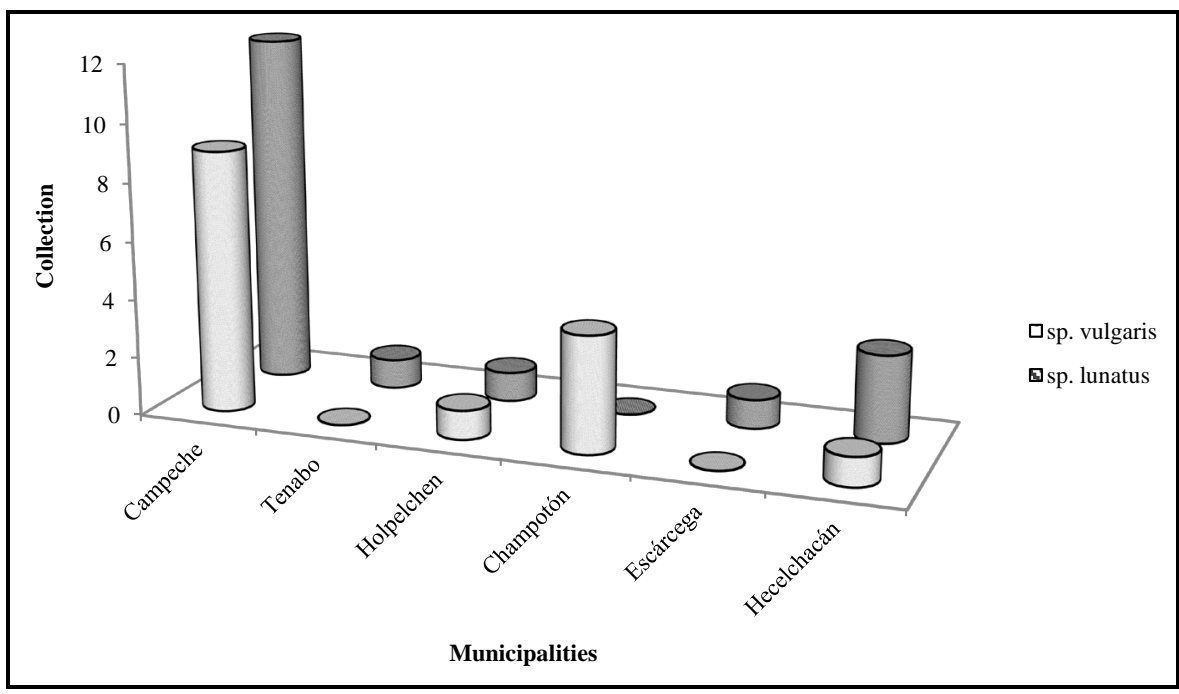

Figure 4. Phaseolus species collected by municipalities.

A pretty good idea related with the relevance of genetic resources is provided by such bean diversity among regional farmers, as well as the in situ germ-plasma preservation, which keeps being used year after year as part of the family heritage [13]. Features such as flavor, cooking quality, yield stability rather than local adaptability and performance are important attributes that lead farmers to preserve their "wild" varieties, keeping the genetic wealth of their communities [14]. 


\subsection{Collected Genetic Variability Preservation and Usage}

An objective of this sample collection was to have the genetic variation revealed in the traditional ecotypes for their future preservation and subsequent improvement. The collected and evaluated samples were sent to the germ-plasma bank based at the National Plant Genetic Resources for Food and Agriculture (SINAREFI), located at the University of Guadalajara in the municipality of Zapopan, Jalisco.

\subsection{Yield}

The yield achieved by the collections that were carried out is shown in Table 2, which revealed higher yields than those $615 \mathrm{~kg} / \mathrm{ha}$ [15] reported in the state of Campeche, having five lunatus and three vulgaris species standing out. The highest yield took place in the mejen ib, the big flat black ibes and the big white ibes, with 2867, 1327 and $1282 \mathrm{~kg} / \mathrm{ha}$, respectively.

The wild varieties potential versus the commercial varieties has been reported by several studies in such regard, mainly concerning yield performance, physical quality and protein content [16] [17]. Additionally, the bean that is both produced and consumed in Mexico comes mainly from native genotypes in lower levels of improved varieties, which have agronomic and quality advantages [18].

The precipitation that took place from the samples planting date (Figure 5), to the harvest for seed increase, was $464 \mathrm{~mm}$, if taking into account that the bean water necessity ranges from 600 to $700 \mathrm{~mm}$ in 3 or 4 months

Table 2. Yield collections of wild beans in the state of Campeche.

\begin{tabular}{ccc}
\hline Species & Common name & Yield $\mathbf{~ k g} / \mathbf{h a}$ \\
\hline \multirow{3}{*}{ lunatus } & Mejen Ib & 2867 \\
& Ibes black plane & 1327 \\
& Ibes white & 1282 \\
& Ibes munition & 1104 \\
& Ibes pinto creole & 788 \\
vulgaris & T'zamáa red sheath & 953 \\
& T'zamáa green sheath & 755 \\
& T'zamáa marbled sheath & 943 \\
\hline
\end{tabular}

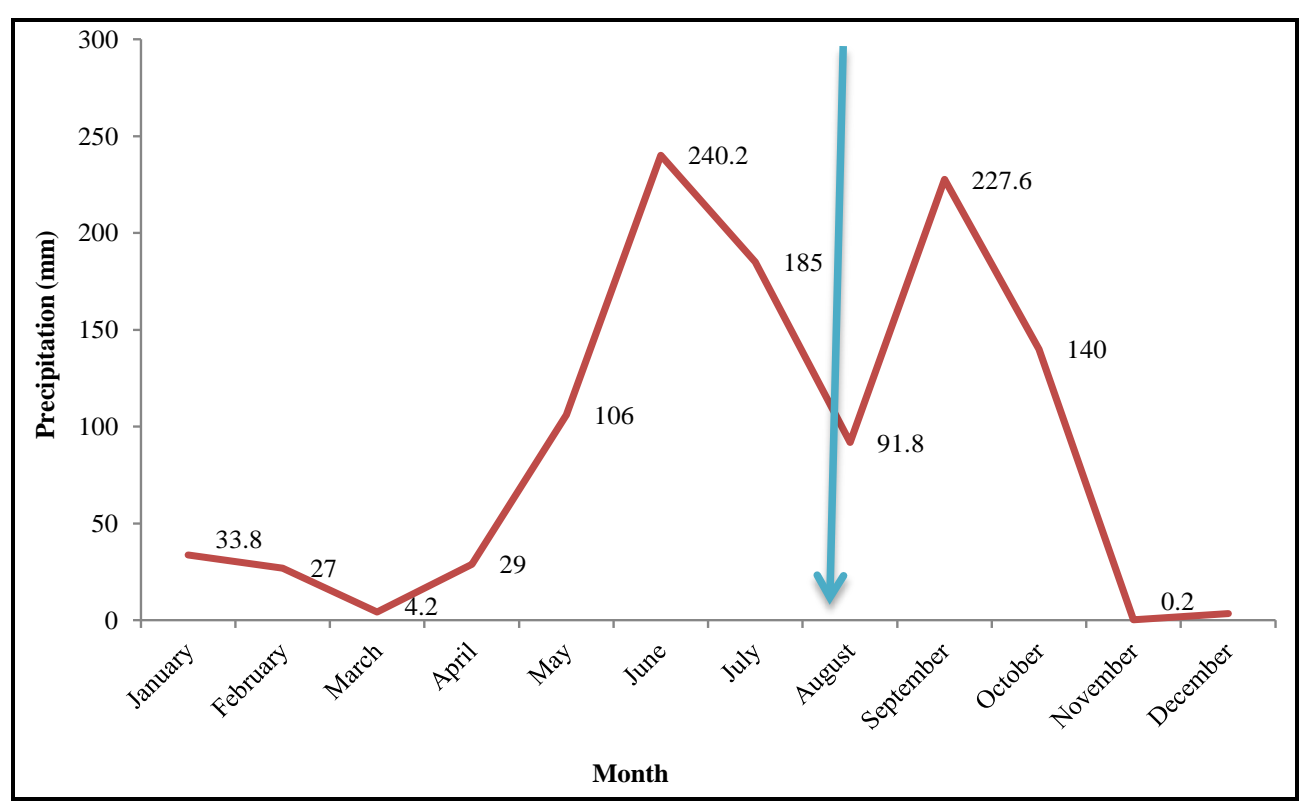

Figure 5. Annual precipitation in the town of Cayal in 2012. The arrow indicates the date of planting material collected for seed increase. 
[19], having only $66 \%$ of the cultivation requirements covered; nonetheless, nine of the collected samples exceeded the $615 \mathrm{~kg} /$ ha yield average statewide (Table 2), proving their tolerance ability to extreme weather conditions. As reported by several studies, wild beans are naturally adapted to survive harsh climatic fluctuations until their final germination, under favorable conditions of subsequent cycles, occurs [20]-[22] as observed in the study hereby. The average temperature recorded during the evaluation was $26^{\circ} \mathrm{C}$, maximum was $36^{\circ} \mathrm{C}$ and minimum of $18^{\circ} \mathrm{C}$, recorded at the end of the crop cycle.

\section{Conclusion}

A total of 33 different types of Phaseolus species were identified and collected in the state of Campeche, out of which 15 belonged to the $P$. vulgaris species and 18 to $P$. lunatus. The diversity of the collected samples was reflected in the range of growth habits from the bush to the indeterminate climbing species, being the latter the most representative, with about 29 samples, many of those due because of how they were planted, which was a process traditionally performed in association with the cultivation of corn. Early samples were identified in this diversity with a 60 to 120 days fluctuating cycle after emergence; samples with a 1.35 to 2.86 t/ha yield potential were obtained in two Phaseolus lunatus samples.

\section{References}

[1] Espinosa-Pérez, E.N., Ramírez-Vallejo, P., Crosby-Galván, M.M., Estrada-Gómez, J.A., Lucas-Florentino, B. and Chávez-Servia, J.L. (2015) Clasificación de poblaciones nativas de frijol común del centro-sur de México por morfología de semilla. Revista Fitotecnia Mexicana, 38, 29-38.

http://www.scielo.org.mx/scielo.php?script=sci_arttext\&pid=S0187-73802015000100005\&lng=pt\&tlng=es.

[2] Ballesteros, P.G., Torres, G.A. and Barrera, M. (2000) Reincorporación del frijol carauta (Phaseolus lunatus L.) a la agricultura tradicional en el resguardo indígena de San Andrés de Sotavento (Córdoba, Colombia). Plant Genetic Resources Newsletter, No. 123, 23-27.

http://www.bioversityinternational.org/fileadmin/user_upload/online_library/publications/pdfs/Plant_Genetic_Resourc es_Newsletter_No_123.pdf

[3] Hernández-López, V.M., Vargas-Vázquez, M.L.P., Muruaga-Martínez, J.S., Hernández-Delgado, S. and Mayek-Pérez, N. (2013) Origen, domesticación y diversificación del frijol común: Avances y perspectivas. Revista fitotecnia mexicana, 36, 95-104. http://www.revistafitotecniamexicana.org/documentos/36-2/1a.pdf

[4] López Soto, J.L., Ruiz Corral, J.A., Sánchez González, J.D.J. and Lépiz Ildefonso, R. (2005) Adaptación climática de 25 especies de frijol silvestre (Phaseolus spp) en la república mexicana. Revista Fitotecnia Mexicana, 28, 221-230. http://www.redalyc.org/articulo.oa?id=61028306

[5] Rivas, M. (2001) Conservación in situ de los recursos fitogenéticos. In: Estrategia en recursos fitogenéticos para los países del Cono Sur. Ed., Programa Cooperativo para el Desarrollo Tecnológico Agroalimentario y Agroindustrial del Cono Sur, Montevideo, 63-76. http://repiica.iica.int/DOCS/B0630E/B0630E.PDF

[6] Peña-Valdivia, C.B., Trejo, C., Celis-Velazquez, R. and López Ordáz, A. (2013) Reacción del frijol silvestre (Phaseolus vulgaris L.) a la profundidad de siembra. Revista mexicana de ciencias agrícolas, 4, 89-102. http://www.scielo.org.mx/scielo.php?script=sci arttext\&pid=S2007-09342013000100007\&lng=es\&tlng=es.

[7] Estrada-Medina, H., Bautista, F., Jiménez-Osornio, J.J.M., González-Iturbe, J.A. and Aguilar Cordero, W.J. (2013) Maya and WRB Soil Classification in Yucatan, Mexico: Differences and Similarities. International Scholarly Research Notices Soil Science, 2013, Article ID: 634260. http://dx.doi.org/10.1155/2013/634260

[8] Schoonhoven, A.V. and Pastor-Corrales, M.A. (1987) Sistema estándar para la evaluación de germoplasma de frijol. Centro Internacional de Agricultura Tropical, Cali, 56.

[9] Martínez-Castillo, J., May-Pa, F., Zizumbo-Villareal, D. and García-Marín, P.C. (2004) Diversidad intraespecífica del ib (Phaseolus lunatus L.) en la agricultura tradicional de la Península de Yucatán, México. In: Chávez-Servia, J.L., Tuxill, J. and Jarvis, D.I., Eds., Manejo de la diversidad de los cultivos en los agrosistemas tradicionales, Instituto internacional de recursos fitogenéticos, Cali, 26-35.

https://books.google.com.mx/books?hl=es\&lr=\&id=6ptxbNgluVkC\&oi=fnd\&pg=PA26\&dq=colecta+de+frijol+cicy\& ots=U5kD4ILlGm\&sig=xQXtjbuJ-g2ORQlA3xq846ey63o\#v=onepage\&q\&f=false

[10] Wicab-Cámara, G.N. and Martínez-Castillo, J. (2011) El frijol maya del siglo XXI. Revista de divulgación científica y tecnológica de la Universidad Veracruzana., 24, 7. http://www.uv.mx/cienciahombre/revistae/vol24num2/articulos/frijol/

[11] Félix, D.-T., Coello-Coello, J. and Martínez-Castillo, J. (2014) Wild to Crop Introgression and Genetic Diversity in Lima Bean (Phaseolus lunatus L.) in Traditional Mayan Milpas from Mexico. Conservation Genetics, 15, 1315-1328. 
http://dx.doi.org/10.1007/s10592-014-0619-7

[12] Martínez-Castillo, J., Camacho-Pérez, L., Coello-Coello, J. and Andueza-Noh, R. (2012) Wholesale Replacement of Lima Bean (Phaseolus lunatus L.) Landraces over the Last 30 Years in Northeastern Campeche, Mexico. Genetic Resources and Crop Evolution, 59, 191-204. http://dx.doi.org/10.1007/s10722-011-9675-8

[13] Lagunes-Espinoza, L.del.C., Gallardo-López, F., Becerril-Hernández, H. and Bolaños-Aguilar, E.D. (2008) Diversidad cultivada y sistema de manejo de Phaseolus vulgaris y Vigna unguiculata en la región de la Chontalpa, Tabasco. Revista Chapingo. Serie horticultura, 14, 13-21. http://www.scielo.org.mx/scielo.php?script=sci arttext\&pid=S1027-152X2008000100003\&lng=es\&tlng=es

[14] Arunachalam, M. (2004) Participatory Conservation: A Means of Encouraging Community Biodiversity. PGR Newsletter, No. 122, 1-6. http://www.bioversityinternational.org/fileadmin/PGR/article-issue_122-art_1-lang_en.html

[15] Servicio de Información y Estadística Agroalimentaria y Pesquera (SIAP) (2015) Sistema de Información Agropecuarias de Consulta (SIACON). Secretaria de Agricultura, Ganadería, Desarrollo Rural, Pesca y Alimentación. Versión 1.1, México, D.F. http://www.siap.gob.mx

[16] Ayala-Garay, O.J., Pichardo-González, J.M., Estrada-Gómez, J.A., Carrillo-Salazar, J.A. and Hernández-Livera, A. (2006) Rendimiento y calidad de semilla del frijol ayocote en el Valle de México. Agricultura técnica en México, 32, 313-321. http://www.scielo.org.mx/scielo.php?script=sci arttext\&pid=S0568-25172006000300007\&lng=es\&tlng=pt

[17] Ramírez-Pérez, A.R., Díaz-Ruiz, R., Jacinto-Hernández, C., Paredes-Sánchez, J.A. and Garza García, R. (2012) Diversidad de frijoles nativos de diferentes regiones del estado de Puebla. Revista mexicana de ciencias agrícolas, 3 , 467-480. http://www.scielo.org.mx/scielo.php?script=sci_arttext\&pid=S2007-09342012000300005\&lng=es\&tlng=es

[18] Muñoz, V.E.E., Rubio, H.D., Bernal, L.I., Garza, G.R. and Jacinto, H.C. (2009) Caracterización de genotipos nativos de frijol del estado de hidalgo, con base a calidad del grano. Agricultura Técnica en México, 35, 426-435. http://www.scielo.org.mx/pdf/agritm/v35n4/v35n4a8.pdf

[19] Villanueva, D.J., Loredo, O.C. and Hernández, R.A. (2001) Requerimientos hídricos de especies anuales y perennes en las zonas media y altiplano de San Luis Potosí. INIFAP. Campo Experimental Palma de la Cruz. Folleto Técnico, 12, 25-26.

[20] Viñals, M.E., Ortiz, R., Ponce, M. and Ríos, H. (2002) Análisis de la diversidad fenotípica de variedades de frijol (P. vulgaris L.) utilizadas por los campesinos en la comunidad La Palma en Pinar del Río. Cultivos Tropicales, 23, 15-19. http://www.redalyc.org/articulo.oa?id=193218105002

[21] Peña-Valdivia, C.B., Hernández, G.E.del.R., Bernal-Lugo, I. and Aguirre, R.J.R. (1999) Seed Quality of Wild and Domesticated Common Bean (Phaseolus vulgaris L.) after Storage. Interciencia, 24, 8-13. http://www.interciencia.org/v24_01/pena.pdf

[22] Sánchez Urdaneta, A.B., Peña Valdivia, C.B., Trejo, C., Aguirre, R.J.R., Cárdenas, E. and Galicia Jiménez, A.B. (2003) Permeabilidad de las membranas radicales de plántulas de frijol (Phaseolus vulgaris L.) silvestre y domesticado bajo déficit de humedad. Interciencia, 28, 597-603. http://uaeh.redalyc.org/articulo.oa?id=33908507 